\section{Comparison of Plastic Mulch and Bare-ground Production and Economics for Short-day Onions in a Semitropical Environment}

\author{
C.S. Vavrina and F.M. Roka
}

Additional index words. Allium cepa, sweet onion, production economics

Summary. In 4 years of research comparing production of short-day onions (Allium cepa L.) on plastic mulch versus bare ground in southern Florida, greater marketable yields were obtained when onions were grown on plastic mulch. R esults showed that in a semitropical environment, white-on-black plastic mulch provided the greatest yield enhancement from increased weight and bulb size. Yield loss due to splitting, while apparent, was not sufficient to reduce the impact of mulch on the increase in individual bulb weight. Adopting plastic mulch for sweet onion production will add between $\$ 400$ and $\$ 500 /$ acre ( $\$ 988$ and $\$ 1,235 /$ ha) of additional operating expenses. While this may increase cash-flow burdens and heighten overall financial risks, the added value from increased yields by weight and greater percentages of jumbo sized bulbs suggest that plastic mulch has an excellent chance to increase a grower's overall net return. $U$ sing conservative yield and market price assumptions, an economic analysis showed an increase in grower's net return of more than $\$ 120 /$ acre (\$296/ ha).
U niversity of Florida, Southwest Florida Research and Education Center, 2686 State Road 29 North Immokalee, FL 34142.

Florida Agricultural Experiment Station journal series $\mathrm{R}-06983$. The cost of publishing this paper was defrayed in part by the payment of page charges. U nder postal regulations, this paper therefore must be hereby marked adverti sement solely to indicate this fact. ore than 36,000 acres $(14,575 \mathrm{ha})$ of short-

day onions (Allium cepa L.) areproduced annually in theU nited States (Georgia Agricultural Statistic Service, 1999). The major sites of production include Arizona, California, Georgia, $\mathrm{H}$ awaii, T exas, and Washington. Short-day onions produced in these areas are known for low pungency and higher sugars and are marketed under such names as $M$ aui Sweets, Sweet Vidalia, or Walla Walla Sweet. M ost varieties are from G ranex (top-shaped onion) breeding lines, but growersin T exasprefer Grano (spherical shaped) varieties.

Production of short-day onions has been economically very successful in the southern U nited States. G eorgia and T exascommand much of the shortday onion market, though asmall shortday onion industry exists in northern Florida. Recent research conducted in southern Florida in Immokalee has shown that short-day onions can be market ready 1 to 2 monthsin advance of other production areas(C.S. Vavrina, unpublished), thus a competitive advantage may exist for southern Florida growers.

Sweet onions have typically been produced on bare ground and established from bare-root transplants. The use of plastic mulch is common for other vegetable production. Southern U.S. growers use black mulch for winter and spring production to encourage increased bed temperature and white-on-black mulch in the fall to reduce bed temperature and improve plant establishment.

Several studies have investigated the production effects of plastic mulch on onions. Hochmuth et al. (1991), reported black mulch increased the yield of medium, large, and extra-large short-day onion bulbs compared to bare-ground culture in the first of 2 years of data in northern Florida. In the second year of their study, an increase in bulb size was noted, but total yield was unaffected. Yaneth-R ondon et al. (1996) compared black, grey, and white polyethylene mulch with bare-ground planting and found the shortest growth cycle and largest 'Yellow G ranex' bulbswere produced under black or grey mulch in Bogota, Colombia. In Japan, Yamashita and Takase (1987) showed better leaf growth and bulb yields in early fall production of onion sets with white- on-black versus black mulch. A detunji (1994) found organic mulches in general, when applied under semiarid tropical conditions in Nigeria, enhanced onion vegetative growth and yield. $\mathrm{H}$ owever, use of transparent polyethylene mulch resulted in significantly higher bulb yield than any of the organic mulches tested. In Korea, Suh and Kim (1991) reported higher soil water content, soil temperature, and onion yields in mulch (transparent or black polyethylene) versus no-mulch conditions across three planting dates (O ctober, $N$ ovember, and $D$ ecember). T otal yield was highest with transparent plastic applied in 0 ctober.

The objectives of this study were 2-fold. First, theimpact of plastic mulch (white-on-black and black) on shortday onion production was compared to thetraditional bare-ground method under southern Florida conditions. It was anticipated that greater yields would be found in at least the black mulch treatment, similar to northern Florida findings of $\mathrm{H}$ ochmuth et al. (1991). The second objective was to estimate the economic costs and benefits of onion production on the plasticulture system.

\section{Materials and methods}

Short-day onion trials were conducted over four seasons (1994-95, 1995-96, 1996-97, 1997-98) at the Southwest Florida R esearch and E ducation Center in Immokalee on an I mmokalee fine sand (sandy, silicaceous, hyperthermic, Arenic $H$ aplaquod). Seeds of 'Yellow Granex Improved' (Sunseeds, Morgan H ill, Calif.) were sown directly into beds [ 4 inches $(10 \mathrm{~cm})$ high, 36 inches $(0.9 \mathrm{~m})$ wide] on or about $150 \mathrm{ct}$. and grown for about 2 months to produce bareroot transplants for setting into the experimental plots (Table 1). An uncontrolled outbreak of stemphylium leaf blight [Stemphylium vesicarium (Waller.) E. Simmons] in the 1996-97 transplant crop precluded the use of the 'Yellow Granex I mproved' (YGR). 'Sweet D ixie' (Rio C olorado Seed C o., Yuma, Ariz.) bare-root transplants, grown for a variety trial at the same location, were used in place of YGR for the 1996-97 study.

For all trials, mulched beds were prepared $14 \mathrm{~d}$ before setting the transplants. A preplant fertilizer of $30 \mathrm{lb} /$ acre $\left(33.6 \mathrm{~kg} \cdot \mathrm{ha}^{-1}\right)$ of $\mathrm{N}$ and $54 \mathrm{lb} /$ acre $\left(60.5 \mathrm{~kg} \cdot \mathrm{ha}^{-1}\right)$ of $\mathrm{K}$ was applied to 
T able 1. C ultivar, cultural practice, and harvest date information from the short day onion on bare ground (BG), whiteon-black plastic (W BP), and black plastic (BP) mulch trials in southwestern Florida. ${ }^{2}$

\begin{tabular}{lllll}
\hline Cultivar & Mulch type & Transplant date & Sidedress date & H arvest date \\
\hline Yellow Granex & BG, WBP & 9 D ec. 1994 & 30 Dec., 31 Jan., 2 M ar. & 18 Apr. 1995 \\
Yellow Granex & BG, WBP & 12 Dec. 1995 & 18 Jan., 20 Feb., 7 M ar. & 6 Apr. 1996 \\
Sweet D ixie & BG, WBP, BP & 10 Dec. 1996 & 10 Jan., 4 and 24 Feb., 17 M ar. & 1 Apr. 1997 \\
Yellow Granex & BG, WBP, BP & 18 D ec. 1997 & 12 Jan., 12 Feb., 14 M ar. & 8 Apr. 1998
\end{tabular}

${ }^{\mathrm{z}} \mathrm{All}$ seed beds planted on or about $15 \mathrm{Oct}$.

the prebedded area. Theland was then broadcast fumigated with $98 \%$ methyl bromide, $2 \%$ chloropicrin [320 lb/ acre $\left(246.4 \mathrm{~kg} \cdot \mathrm{ha}^{-1}\right)$ ] from $\mathrm{G}$ reat $\mathrm{L}$ akes Chemical Corp. (W est L afayette, Ind.) to reduce the possibility of soilborne disease. $L$ and was bedded to a height of 8 inches $(20 \mathrm{~cm})$ via a bed press (Kennco, Ruskin, Fla.) and immediately covered with $0.3-\mathrm{mil}$ [0.0003inch $(0.008-\mathrm{mm})$ ] white-on-black plastic (WBP) mulch (Sonoco Plastics, $\mathrm{H}$ artsville, S.C.). WBP and bareground (BG) treatments were studied in all four seasons. Black plastic mulch (BP) was only evaluated in the 199697 and 1997-98 seasons (Table 1). BG plots were established by cutting and removing the WBP mulch applied after fumigant action. BP plots were prepared by replacing the initial WPB with BP (0.3-mil, Sonoco Plastics, $\mathrm{H}$ artsville, S.C.).

All onion plots were side dressed three times at 30-d intervals with 30 $\mathrm{lb} / \mathrm{acre}\left(33.6 \mathrm{~kg} \cdot \mathrm{ha}^{-1}\right)$ of $\mathrm{N}$ and $54 \mathrm{lb} /$ acre $\left(60.5 \mathrm{~kg} \cdot \mathrm{ha}^{-1}\right)$ of $\mathrm{K}$ during the 120-d growing period (mean for the four seasons). Side dressing in the case of mulched beds was applied by puncturing the plastic and penetrating the soil to a depth of 4 inches $(10 \mathrm{~cm})$, then placing the calculated amount of fertilizer in each hole. The holes were evenly distributed along the shoulder of the bed (i.e., modified bands) to allow for uniform distribution of fertilizer. Subsurface seepage irrigation insured fertilizer dissolution and uptake. Individual onion plots measured $15 \mathrm{ft}(4.6 \mathrm{~m})$ long and 32 inches $(0.8$ $\mathrm{m})$ wide on 6 - $\mathrm{ft}(1.8-\mathrm{m})$ centers. $0 \mathrm{n}$ ion transplants were set 4 inches (10 $\mathrm{cm}$ ) apart in a twin-row pattern with 10 inches $(25.4 \mathrm{~cm})$ between rows. This arrangement resulted in 90 plants per plot. A randomized completeblock design with six replications was employed each season with the exception of the 1997-98 season in which nine replications were used. D ata on marketable weight, number, and size cat- egories were analyzed by analysis of variance using SAS version 6.04 (1987) with Fischers protected LSD performed when significance was found.

Partial budgeting techniqueswere used to estimate the change in per acre net returns from using plastic mulch. Partial budgeting considers only incremental changes in revenues and costs from a change in production practices. In this research, the additional cost of plastic was compared against the revenue attributable to changes in overall yield and percentages of jumbo sized bulbs. 0 ther in put costssuch asseed, fertilizer, and chemicals were assumed to be unaffected by plastic mulch. A change in per acre net returns was calculated by subtracting added per acre costs from estimated increases in revenue.

\section{Results and discussion}

A nalysis of the data from the four seasons revealed significantly greater marketable onion yield with WBP mulch than with theBG culture ( $T$ able $2)$. Yield enhancement was a function of increased bulb weight, since the number of onions was held constant across experimental plots ( 90 per plot). There was a 29\%increase in individual bulb weight under WBP mulch compared to BG.

The bulb weight response was further evaluated by separating yield into size categories (T able 3). Because onions from the 1994-95 season were not sized, they were not included in this analysis. A significant season by treatment interaction $(P \leq 0.05)$ was found for bulb size. Subsequent analysis of the data by season showed that in the 1995-96 and 1997-98 seasons, WBP production yielded more jumbo bulbs [ $>4$ inch $(>10 \mathrm{~cm})$ ] than the BG treatment. By comparison theBG production yielded moreextra-large bulbs [3.0 to 4.0 inch $(7.5$ to $10 \mathrm{~cm})$ ] than WBP plots. A similar response was noted in the 1996-97 season where the WBP treatment yielded more extra-large onions than the BG treatment. Whether for environmental or varietal reasons, the jumbo onion yield in the 1996-97 season was essentially nonexistent. Thus, resultsfrom all three seasons demonstrated that mulching

Table 2. O nion yield per plot over four seasons on bare ground or white-onblack plastic mulch.

\begin{tabular}{|c|c|c|c|}
\hline T reatment & $\begin{array}{c}\text { Marketable } \\
\text { no. }\end{array}$ & $\begin{array}{c}\text { Marketable } \\
\text { wt }^{\mathbf{z}} \\
\text { (Ib) }\end{array}$ & $\begin{array}{c}\text { Avg bulb } \\
\text { wt } \\
\text { (Ib) }\end{array}$ \\
\hline \multicolumn{4}{|l|}{ Season } \\
\hline 1994-95 & 80.33 & 57.17 & 0.713 \\
\hline 1995-96 & 82.75 & 71.87 & 0.871 \\
\hline 1996-97 & 83.75 & 35.47 & 0.423 \\
\hline 1997-98 & 76.17 & 52.39 & 0.692 \\
\hline $\operatorname{LSD}_{0.05}$ & 3.73 & 4.85 & 0.052 \\
\hline \multicolumn{4}{|l|}{ Culture } \\
\hline Bare ground & 82.00 & 48.00 & 0.585 \\
\hline White-on-black plastic & 79.46 & 60.45 & 0.765 \\
\hline $\begin{array}{l}\operatorname{LSD}_{0.05} \\
\text { Significance }\end{array}$ & --- & 3.43 & 0.037 \\
\hline Season & $* *$ & $* *$ & $* *$ \\
\hline Culture & NS & $* *$ & $* *$ \\
\hline Seaso $n \times$ culture & NS & NS & NS \\
\hline
\end{tabular}


T able 3. Season $\times$ culture [white-on-black (WBP) plastic mulch versus bare ground (BG)] interaction results over three seasons; yields expressed on a per-plot basis.

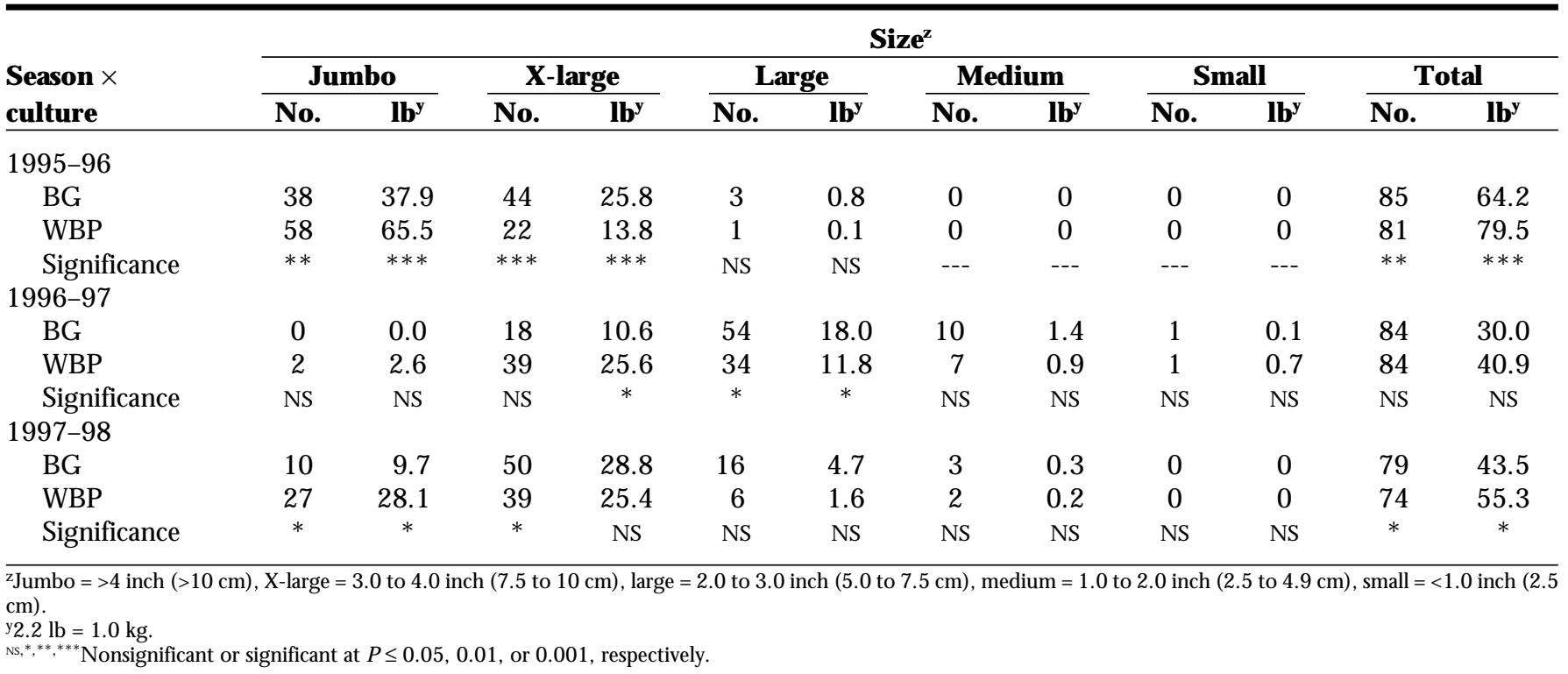

enhanced size. Additionally, data from two of the three seasons revealed that overall marketable weight was significantly higher for the WBP treatments than the BG treatments (1995-96 and 1997-98), and a similar trend was evident in the 1996-97 season.

The 1996-97 and 1997-98 trials included black plastic (BP) mulch plots to determine if mulch color would affect yield response. Both mulch treatments provided higher yields [mean weight per plot for two seasons: $B G=$ $38.1 \mathrm{lb}(17.3 \mathrm{~kg}), W B P=49.7 \mathrm{lb}$ $(22.5 \mathrm{~kg}), B P=46.5 \mathrm{lb}(21.1 \mathrm{~kg})$; $\mathrm{LSD}_{0.05}=5.82(2.65)$ ]. A significant season by treatment interaction was found for onion size $(P \leq 0.05)$, neces- sitating further analysis(T able4). Both mulches enhanced the yield of larger size onions (extra-large in 1996-97, jumbo in 1997-98) when compared to the BG treatment, similar to the pattern discussed above with WBP versus BG. H owever, when comparing mulch treatments (WBP versus $B P), W B P$ resulted in a greater yield of jumbo onions in 1997-98 and a tendency toward more extra-large onions in 1996-97. O verall marketableweight was not significantly different between mulch types.

Past research with mulch versus nonmulch conditions found that greater onion yield in mulch treatments was likely related to the conser- vation of fertilizer (Adetunji, 1994) and moisture (Suh and Kim, 1991), and it was assumed that the yield enhancement found in the current study was also associated with these factors. The influence of mulch on bed temperature can be an asset or a detriment depending on mulch color and time of planting (Yamashita and Takase, 1987). In the current research, bed temperatures during bulbing were comparable, especially for WBP and $B G\left[B G=90^{\circ} \mathrm{F}\left(32^{\circ} \mathrm{C}\right), W B P=88^{\circ} \mathrm{F}\right.$ $\left.\left(31^{\circ} \mathrm{C}\right), \mathrm{BP}=100^{\circ} \mathrm{F}\left(38^{\circ} \mathrm{C}\right)\right]$. There may have been a temperature benefit from mulch during the seedling phase of production, but this was not measured.

T able 4. Onion yield per plot comparing bare ground (BG) culture to onions grown on either white-on-black (W B P) or black plastic (B P) mulch in the 1996-97 season.

\begin{tabular}{|c|c|c|c|c|c|c|c|c|c|c|c|c|c|}
\hline \multirow{3}{*}{\multicolumn{2}{|c|}{ T reatment }} & \multicolumn{12}{|c|}{$\operatorname{Size}^{z}$} \\
\hline & & \multicolumn{2}{|c|}{ Jumbo } & \multicolumn{2}{|c|}{ X-large } & \multicolumn{2}{|c|}{ L arge } & \multicolumn{2}{|c|}{ Medium } & \multicolumn{2}{|c|}{ Small } & \multicolumn{2}{|c|}{ T otal } \\
\hline & & No. & $\mathbf{I b}^{\mathbf{y}}$ & No. & $\mathbf{I b}^{\mathbf{y}}$ & No. & $\mathbf{I b}^{\mathbf{y}}$ & No. & $I^{y}$ & No. & $\mathrm{Ib}^{y}$ & No. & $\mathbf{I b}^{y}$ \\
\hline \multirow[t]{4}{*}{1996} & $B P$ & 1 & 1.6 & 34 & 20.6 & 38 & 12.0 & 8 & 0.9 & 1 & 0.1 & 82 & 35.2 \\
\hline & WBP & 2 & 2.6 & 39 & 25.6 & 34 & 11.8 & 7 & 0.9 & 1 & 0.1 & 84 & 40.9 \\
\hline & $B G$ & 0 & 0.0 & 18 & 10.6 & 54 & 18.0 & 10 & 1.4 & 2 & 0.2 & 84 & 30.0 \\
\hline & & \multicolumn{12}{|c|}{ Yellow Granex } \\
\hline \multirow[t]{4}{*}{1997} & $\mathrm{BP}$ & 21 & 21.0 & 45 & 28.8 & 7 & 2.3 & 1 & 0.1 & 0 & 0.0 & 74 & 52.2 \\
\hline & WBP & 27 & 28.1 & 39 & 25.4 & 6 & 1.6 & 2 & 0.2 & 0 & 0.0 & 74 & 55.3 \\
\hline & $B G$ & 10 & 9.7 & 50 & 28.8 & 16 & 4.7 & 3 & 0.3 & 0 & 0.0 & 79 & 43.5 \\
\hline & $\operatorname{LSD}_{0.05}$ & 4.8 & 4.9 & 8 & NS & 4 & 1.2 & NS & NS & NS & NS & 4 & 4.1 \\
\hline
\end{tabular}

z $\mathrm{umbo}=>4$ inch $(>10 \mathrm{~cm}), \mathrm{X}$-large $=3.0$ to 4.0 inch $(7.5$ to $10 \mathrm{~cm})$, large $=2.0$ to 3.0 inch $(5.0$ to $7.5 \mathrm{~cm})$, medium $=1.0$ to 2.0 inch $(2.5$ to $4.9 \mathrm{~cm})$, small $=<1.0$ inch $(2.5$ $\mathrm{cm})$.

$\mathrm{y} 2.2 \mathrm{lb}=1.0 \mathrm{~kg}$.

${ }^{\mathrm{NS}} \mathrm{N}$ onsignificant. 
Table 5. Culls generated by splitting (vegetative reproduction) by year over bare ground (B G), white-on-black plastic (W B P), or black plastic (BP) mulch types.

\begin{tabular}{|c|c|c|c|c|c|c|c|c|}
\hline \multirow[b]{2}{*}{ Treatment } & \multicolumn{2}{|c|}{ 1994-95 } & \multicolumn{2}{|c|}{ 1995-96 } & \multicolumn{2}{|c|}{ 1996-97 } & \multicolumn{2}{|c|}{ 1997-98 } \\
\hline & No. & $I b^{y}$ & No. & $I^{\prime} b^{y}$ & No. & $I \mathbf{b}^{y}$ & No. & $I \mathbf{b}^{y}$ \\
\hline$B G$ & 4 & 3.4 & 6 & 6.1 & 4 & 2.0 & 10 & 7.0 \\
\hline WBP & 4 & 4.4 & 11 & 13.9 & 3 & 1.8 & 15 & 14.7 \\
\hline BP & --- & --. & --- & --- & 5 & 3.3 & 16 & 13.4 \\
\hline Significance & NS & NS & $* *$ & ** & NS & NS & * & $* * *$ \\
\hline
\end{tabular}

$\mathrm{z} 2.2 \mathrm{lb}=1.0 \mathrm{~kg}$

$\mathrm{NS}^{*}, * *,{ }^{* * *} \mathrm{~N}$ onsignificant or significant at $\mathrm{P} \leq 0.05,0.01$, or 0.001 , respectively.

There was a tendency for onions to undergo more asexual reproduction or splitting in the mulched treatments (Table 5.) This was apparent in 1995-96 (WBP versus BG) and in 1997-98 (WBP and BP versus BG). Plastic mulch has been shown to advance maturity in other crops (B rown et al., 1991; Wilson et al., 1987). In onions, Suh and K im (1991) noted an increase in the level of bolting when onions were planted in $\mathrm{O}$ ctober on a transparent polyethylene mulch. $\mathrm{H}$ wang et al. (1996) have shown seed yieldsfrom polyethylene mulched plots can be $>40 \%$ higher than from bareground cultivation. It is hypothesized that in the current research, plastic mulch may have advanced onion maturity resulting in more splitting compared to the BG-grown onions. Another possible explanation is the plant spacing. L.M. Pike and W. Randle (personal communication) have indicated that splitting is a function of spacing, and it may be that tighter spacing could have alleviated this situation. O nions that had split were not included in the marketable yield data as presented above.

D ecember through A pril is generally considered the dry season in Florida. H owever, the 1997-98 season occurred during an $\mathrm{EI} \mathrm{N}$ iño year in which about 15.75 inches $(40 \mathrm{~cm})$ of rainfall was recorded from $D$ ecember to April. $\mathrm{H}$ eavy rainfall washed out the $B G$ plots on several occasions during this period, dislodging the plants and necessitating rebedding, at additional cost. Russo et al. (1997) noted the benefits of plastic mulch in preventing erosion of sweet-onion beds. Although prevention of erosion and other factors such as weed control may need to be considered in the production of onions on mulch vs. bare ground, it would be important to first determine whether the cost of mulch in onion production can be justified.
Economic considerations. Costs for standard grade WBP $\{5 \times 4,800 \mathrm{ft}$ $(1.5 \times 1,463 \mathrm{~m}) \times 1.0 \mathrm{mil}[0.001$ inches $(0.025 \mathrm{~mm})]$ thick $\}$ are estimated to be $\$ 470 /$ acre $(\$ 1,161 / \mathrm{ha})$. E ach acre would require 1.5 rolls (3.7 rolls/ ha) or $\$ 300$ ( $\$ 741 /$ ha) of plastic material at $\$ 200$ per roll. Plastic application costs are $\$ 10 /$ acre $(\$ 25 /$ ha). Cleanup and disposal costs are $\$ 160 /$ acre (\$395/ ha) (Smith and Taylor, 1997).

Averaging across the three seasons in Table 3 , total marketable weights were $29 \%$ higher from the WBP treatments. If BG production yields $25,000 \mathrm{lb}(11,340 \mathrm{~kg})$ of onions, the predicted yield from using WBP would be $32,250 \mathrm{lb}(14,628 \mathrm{~kg})$. D ry onionsare sold in $50-\mathrm{lb}(22.6-\mathrm{kg})$ sacks or cartons. Converting marketable weight into sacks would indicate that WBP yields an additional 145 sacks/ acre (358 sacks/ ha) over what would have been produced on BG. Dividing the additional costs associated with WBP [ $\$ 470 /$ acre $(\$ 1,161 /$ ha)] by the additional sacks of onions produced from WBP [145 sacks/ acre (358 sacks/ ha) ], providesabreak-even price. Given the above data, so long as theonion market priceisabove $\$ 3.25 /$ sack, it is profitable to lay WBP.

The costs of laying and disposing of plastic are independent of onion yields. In other words, $\$ 470 /$ acre $(\$ 1,161 / \mathrm{ha})$ is the estimated additional cost of plastic regardless of whether final yields are 100 or 1,000 sacks/ acre (250 or 2,500 sacks/ ha). $\mathrm{H}$ owever, higher yields lower the break-even price. For example, if expected yields from BG production increase from 500 to 800 sacks/ acre (1,235 to 1,976 sacks/ ha), the corresponding increase in extra yield from WBP should increase from 145 to 232 sacks/ acre (358 to 573 sacks/ ha). The break-even price decreasesfrom $\$ 3.25$ to $\$ 2.03$ per sack.
Estimating arevenueben efit from plastic requires information on sweet onion market price. $M$ arket prices for sweet onions were not available for southern Florida shipping points. Instead, onion priceswere collected from M cAllen, T exas, the shipping point for sweet onionsgrown in the $\mathrm{R}$ io $\mathrm{G}$ rande Valley and the growing area which most closely coincided with harvest dates of the southwest Florida study (VanSickle, 1999). Table 6 presents a 4-year history of April prices in M cAllen, Texas. During three of the four seasons, onions in southwest Florida were harvested between 1 and 8 A pr. Since 1994, thelowest reported price during the first week of A pril was $\$ 3.75$ per sack of medium grade onions. Assuming that plastic increases onion yields by 145 sack/ acre (358 sacks/ ha) and that additional costs from plastic were $\$ 470 /$ acre $(\$ 1,161 /$ ha), WBP culture increased net returns by $\$ 73.75 /$ acre ( $\$ 182 /$ ha). N et returns on plastic mulch increase with higher yields and more favorable market prices.

R esultsfrom T able 3 also indicate that plastic mulch produced a higher percentage of jumbo onions which translates into a second and separate economic benefit. Jumbo sizes typically command a market premium. Since 1994, the early A pril (1-14 Apr.) price premium for jumbo onions ranged between $\$ 0.25$ to $\$ 4.00$ per sack higher than medium, the next marketable grade (Table 6). As the marketing season progresses, price premiums shrink, and in 1994 and 1996 even reversed to pay a slight premium on smaller sized, medium onions.

Averaging across the three seasons in Table 3 , the percentage of jumbo sizes from $B G$ production was $74 \%$ By contrast, $88 \%$ of the onions grown under WBP graded as jumbos. As outlined in Table 7, additional revenue solely from a percentage change 
Table 6. M cAllen, T exas, shipping point prices per $50-\mathrm{lb}(22.7-\mathrm{kg})$ sacks of dry bulb spring onions. ${ }^{2}$

\begin{tabular}{|c|c|c|c|c|c|c|c|c|}
\hline & \multicolumn{8}{|c|}{ Price (\$) } \\
\hline & \multicolumn{8}{|c|}{ Size } \\
\hline & \multicolumn{4}{|c|}{ Jumbo } & \multicolumn{4}{|c|}{ Medium } \\
\hline & 1994 & 1995 & 1996 & 1997 & 1994 & 1995 & 1996 & 1997 \\
\hline 1-7 Apr. & 5.00 & 18.00 & 4.75 & 9.00 & 4.25 & 14.00 & 3.75 & 6.50 \\
\hline 8-14 Apr. & 4.25 & 16.00 & 4.50 & 11.00 & 4.00 & 14.00 & 4.25 & 8.00 \\
\hline 15-21 Apr. & 4.00 & 14.00 & 3.75 & 10.50 & 4.50 & 12.00 & 4.25 & 7.50 \\
\hline $22-28 \mathrm{Apr}$. & 3.50 & 10.00 & 3.50 & 10.00 & 4.00 & 7.50 & 4.00 & 8.00 \\
\hline
\end{tabular}

zM edian of the Wednesday price range reported in the table (VanSickle, 1999).

Table 7. E stimating the revenue gain from producing a greater percentage of jumbo onions ( 1 sack/acre $=2.47$ sacks/ha, 1 $\mathrm{kg}=2.2 \mathrm{lb})$.

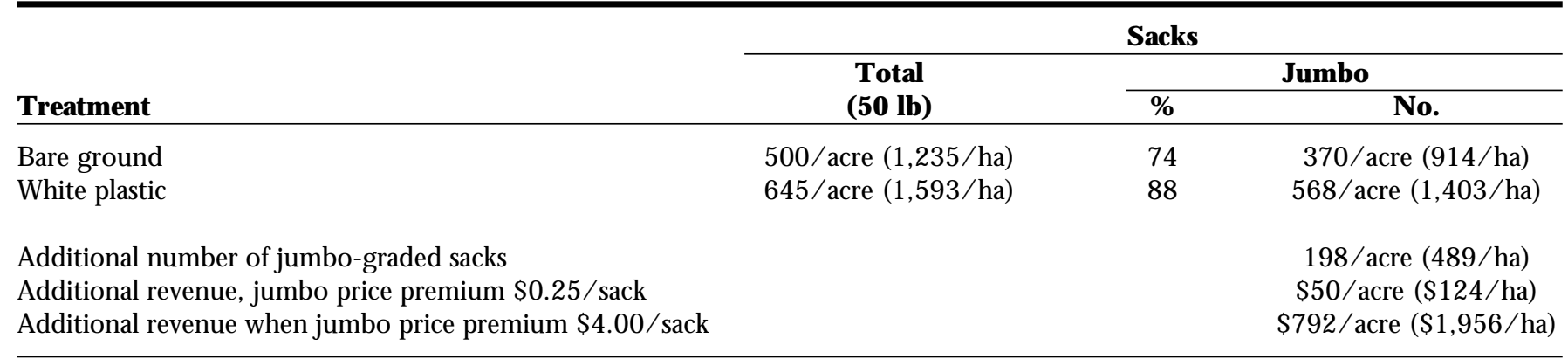

in marketing grade ranged between $\$ 50$ and $\$ 792 /$ acre $(\$ 124$ and $\$ 1,956 /$ ha), depending on the magnitude of the pricepremium for jumbo sizes. Since no additional costs are associated with a change in grade, the added revenues translate directly into increased net returns.

Total economic benefit from using plastic mulch combines the value of higher yield by weight and the additional revenue from marketing higher valued jumbo sizes. Conservative yield estimates, market prices, and grade premiums suggest that plastic mulch increases net returns by more than $\$ 120 /$ acre ( $\$ 296 / \mathrm{ha}), \$ 73.75 /$ acre ( $\$ 182 /$ ha) higher returnsfrom selling more sacks and $\$ 50 /$ acre ( $\$ 124 / \mathrm{ha})$ from selling a higher percentage of jumbo sizes.

Whenever an agricultural producer increases operating costs, risks from crop failuresare magnified. While no evidence exists to suggest that plastic mulch increases the probability of crop failure, the grower who utilizes plastic will commit almost $\$ 500 /$ acre $(\$ 1,250 / \mathrm{ha})$ of additional cost. Without the assurance of a harvestablecrop, committing more input cost increases a grower's financial risk. Furthermore, within the growing season, the added cash expense of plastic mulch will adversely effect a grower's cash flow position.

\section{Literature cited}

Adetunji, I.A. 1994. Response of onion to soil solarization and organic mulching in semi-arid tropics. Scientia H ort. 60:161166.

Brown, J.E., W.D. Goff, W. H ogue, M.S. West, C. Stevens, V.A. Khan, B.C. Early, and L.S. Brasher. 1991. Effects of plastic mulch color on yield and earliness of tomato. Proc. N atl. Agr. Plast. Congr.Amer. Soc. Plasticult. (23rd), p. 21-28.

Georgia Agricultural Statistics Service. 1999. Georgiafarm report. vol. 99, N 0.08 (p2), 23 Apr. http:/ / www.nass.usda.gov/ ga/ frmrpt08.pdf. Accessed 30 June 1999.

Hochmuth, G.J., R.C. Hochmuth, E.A. $H$ anlon, and M .E. D onley. 1991. Polyethylene mulch affects yield of sweet onions in Florida. Suwannee Valley Ag. Res. Educ. Cent. Res. Rpt. 91-12.

H wang, H.J., J.K. Suh, I.J. H a, and Y.W. Ryu. 1996. Effects of planting time and mulching material on growth and seed yield for seed production culture in onion. Res. R pt. Rural D evel. Admin. J. Agr. Sci. Hort. 38:640-647 (CAB Abstr. No. 970303055).

Russo, V.M., B. Cartwright, and C.L. Webber, III. 1997. Mulching effects on erosion of soil beds and on yield of autumn and spring planted vegetables. Biol. Agr. H ort. 14:85-93.

SAS Institute. SAS/ STAT software: version 6.04. 1987. SAS I nst., Cary, N.C.
Smith, S. and T. T aylor. 1997. Production costsfor selected Florida vegetables. U niv. Fla. Coop. Ext. Serv. Circ. 1202.

Suh, J.K. and Y.B. Kim. 1991. Study of improvement of mulching culture method in onion. I. Influence of mulch materials and times on growth and yield. Res. Rpt. Rural D evel. Admin. H ort. 33:31-36 (CAB Abstr. N o. 940304264).

VanSickle, J. 1999. The U niversity of Florida market information system. Archived data of M CAllen, TX, shipping point prices, 1994-97. http:/ / mis.ifas.ufl.edu/cgi-bin/ barc/ barc? $a=d \& k=f v$. Accessed $3 \mathrm{~J}$ une 1999.

Wilson, M.A., P. M olahlane, V. Khan, and C. Stevens. 1987. Influence of earliness and yield of watermelons and muskmelons on row covers and black plastic mulch. Proc. N atl. Agr. Plast. Congr. N atl. Agr. Plastics Assn. 20:264-269.

Yamashita, F. and N. T akase. 1987. Studies on the culture of onion sets. II. I mprovement to growing methods by use of a film mulch which modifies the rise in soil temperature. Res. Bul. Aichi-ken Ag. Res. Cent. 19:148-155 (CAB Abstr. No. 890355058).

Yaneth-Rondon, S., N. Torres-Becerra, $H$. L averde-Pena, H. Pinzon, and S.Y. Rondon. 1996. Effecto de tres coberturas plasticas y dos sistemas de siembra en la fenologia de la cevolla de bulbo (Allium cepa) en la Sabana de Bogata. Agron. Colombiana 13:142-151. 